\title{
Kentsel Politik Ekoloji Literatürü İçerisindeki Tartışmalar: Milieu Fikri Bir Çözüm Olabilir mi?
}

\author{
Ebru Tekin Bilbil ${ }^{1}$ \\ ORCID: 0000-0001-9916-1047
}

Öz

Bu makale, disiplinler arası bir araştırma alanı sunan Kentsel Politik Ekoloji (KPE) literatürünün nasıl yeni fikirlere ve kavramlara açık olduğunu göstermeye çalışırken aslında bu yeni alanda karşılaştığı sorunları vurgulamayı ve bu sorunlara çözüm önermeyi amaçlar. Bu yeni sayılan KPE literatürü, şehir kavramı, kentsel-kırsal ayrımı, metodoloji sorunu ve benzeri konularla ilgili yeni tartışmalar yapılmasını önerir fakat yine de tam başarılı olamaz. Bu makale, KPE literatürü üzerinden bu kavramsal sorunları tartışmaya açar. KPE içerisindeki kuramsal tartışmalarda göz ardı edilen milieu kavramını harekete geçirmeyi amaçlar. Böylelikle bu tartışmalara katkı sağlamayı hedefler. Makale, üç amacı içerir: Birincisi, kentsel politik ekoloji araştırma programının farklı kuramsal okumalar, farklı sorun alanları ve farklı kavramsallaştırma biçimleri ile çerçevesinde incelenmesi; ikincisi, son 15 yıllık süreyi kapsayan bu yeni literatür içerisindeki kuramsal tartışmaların irdelenmesi; üçüncüsü, bu tartışmalara hitaben milieu (kentsel ortam) kavramının önerilmesini içerir. Bu çalışma kuramsal bir tartışma içerdiğ i için yöntem olarak ikincil kaynaklara dayalı bir araştırma metodolojisi izler.

Anahtar Kelimeler: Kentsel Politik Ekoloji, Milieu, Siyaset, Deleuze, Foucault.

${ }^{1}$ Dr. Öğretim Üyesi, Özyeğin Üniversitesi, E-mail: ebrutekin@hotmail.com

idealkent @ C Kent Araştırmaları Dergisi (Journal of Urban Studies)

http://idealkentdergisi.com

Geliş Tarihi Received Date: 11.07.2019 Kabul Tarihi Accepted Date: 31.12.2019 


\title{
Discussions within the Urban Political Ecology Literature: Does the Concept of Milieu Offer a Solution?
}

\author{
Ebru Tekin Bilbil ${ }^{2}$ \\ ORCID: 0000-0001-9916-1047
}

\begin{abstract}
This article analyzes the Urban Political Ecology (UPE) literature as an interdisciplinary field of research by examining its emerging ideas and concepts. This literature urges new discussions regarding the concept of the city, the urban-rural distinction, the methodology problem with comprehensive empirical analyses. Despite this, there are still gaps in understanding social transformations and changes with the concepts of cyborg, planetary urbanization, metobolism, hybrid and so on. This article addresses these constraints by means of the concepts and discussions revealed within the literature of UPE. Therefore, by mobilizing the term of milieu, which is largely ignored in theoretical discussions within UPE, this article aims to contribute to the conceptual and empirical problems of the UPE literature. First, this paper analyzes the urban political ecology research program with different theoretical frameworks, different problem areas and different forms of conceptualization. Second, it examines the theoretical debates in the last 15 years. Third, the concept of milieu is addressed in order to contribute to these discussions. The study follows a research methodology based on secondary sources, since it includes a theoretical discussion.
\end{abstract}

Keywords: Urban Political Ecology, Milieu, Politics, Deleuze, Foucault.

\footnotetext{
${ }^{2}$ Asst. Prof., Özyeğin University, E-mail: ebrutekin@hotmail.com

idealkent (c) Kent Araştırmaları Dergisi (Journal of Urban Studies) 


\section{Giriş}

Gilles Deleuze ve Felix Guattari (1987) kategoriler arasındaki anlamlar ve k1sıtları tartışırken tekniğin sosyal ya da doğal olandan ayrı olmadığını vurgular. Son 15 yıllık bir sürede ortaya çıkan Kentsel Politik Ekoloji (KPE) literatürü de bu ayrımları reddederek kent, doğa, kır, taşra kavramlarının genel geçer anlamlarının ötesindeki ilişkisel bağlantılarını irdeler. Bu makale, bu yeni literatürün incelemesini yapmak ve literatürün kendi içerisinde tartış1lan sorun alanlarını analiz etmeyi amaçlar. Bunu yaparken de yeni oluşan bu literatürün imkân ve kısıtlarını da canlı tutmaya ve bu kısıtları aydınlatacak yeni kavramları harekete geçirmeye çalışır.

KPE literatürü kentlerin kırsala ve kentin çeperlerine bağlı olduğunu ileri sürerken kentlerin başlı başına yekpare ve tekil olmadıklarını bu sebeple de kendi sınırları içerisinde değerlendirilemeyeceğini vurgular ${ }^{3}$. KPE ile kentleşme pratiklerinin oluşum ve üretim süreçlerinin toplumsal ve tarihsel zemine gömülü olduğu öne sürülür. Bu süreçlerin insanlar arası ve insan ile insan-olmayan arası iktidar ilişkilerinden etkilenmesi; bu süreçlerin dinamikleri; sebep olduğu olası istikrarsızlıklar, süreksizlikler ve çatışmalar incelenir. Bu açıdan, pratikler, söylemler, sosyal ilişkiler ile doğa ve toplumsal ilişkiler bir arada irdelenir. Bu evrilme sürecinde kentte çevresel ve sosyal değişimin birbirini belirleyici süreçler olarak ortaya çlkmasına işaret edilirken bu süreçlerde daha demokratik siyasetin uygulanabilmesi önerilir (Heynen, 2014). KPE, kim kimin için sosyo-ekolojik konfigürasyonlar üretir sorusu üzerinden farklı toplumsal ve siyasi dinamikleri irdeler ve adil olmayan süreçleri açığa çıkarır. Bu bir tür kentsel çevrenin sosyo-materyal inşası olarak da dile getirilebilir (Lawhon, Ernstson ve Silver, 2014).

Türkiye'den araştırmacılar ise, KPE üzerinden kentin doğasını, yeni kentleşme söylemi, pratikleri ve süreçlerini ve bunlarla birlikte ortaya çıkan çatışmalı ve çetrefilli yeni siyaset alanlarını irdeler. Örneğin, Yeni İstanbul Çalışmaları kitabı ile Bengi Akbulut ve Ayfer Bartu Candan kapalı siteler, su kullanımı ve mega projeleri; Mekanda Adalet Derneği çalışmaları ile Yaşar Adanalı ve Sinan Erensü, farklı ampirik çalışmalar ile kentin doğasının adaletsiz kullanımı ve toplumsal hareketliliklere işaret eden Suna Kafadar ve Sezai Ozan Zeybek (Zeybek, 2011; 2016), atık politikası incelemesi ile Gül Tuçaltan,

\footnotetext{
${ }^{3}$ Maria Kaika'nın, KPE literatürünün çıkış argümanları ile ilgili kısa videosu için tıklayınız: https://vimeo.com/180669461. Ayrıca, KPE okuması üzerinden bir foto-yazı örneği için, Bkz: Ek-1.
} 
antroposen yaklaşımları eleştiren Emrah Altınok, Zeynep Enlil; kent ve çevre tarihi çalışmaları ile Çiğdem Kafescioğlu (Beyond Istanbul, 2019).

KPE'nin temel amaçları arasında, kentsel ekolojinin sosyal bilimlerin diğer alanları ile nasıl ilişkili olabileceğini anlayabilmek; zeminde ve sahada yerel anlamda elde edilen verilerin uluslararası örneklerdeki ve demokratikleşmedeki anlamını ortaya çıkarmak; toplumsal sorunları anlamak ve bunlara çözüm getirebilmek için yeni araştırma alanları ve kavramları keşfetmek yer alır. Kentlerin çöpleri ve su tüketimi, kentlere enerji tahsisi, kent yönetiminin hesap verebilirliği ve denetimi, mega projelerin yarattı̆̆ çevre tahribatı, gida güvenliği ile kentin sürdürülebilirliğine katkı sağlanması, kent köyleri, alternatif gıda ağları, vb. konular KPE'nin çalışma alanına girer. Bu konuların her birinin farklı yönetimsel, siyasi, kültürel, sosyolojik ve iktisadi alanları içerdiği bu alanları çapraz kesen doğrusal, çok yönlü ve çok boyutlu asamblaj, kentsel ortam, milieu ve kolektiflerden bahsedilebilir4

Bu makale, disiplinler-arası bir araştırma alanı sunan KPE'nin disiplinler ötesi alanda nasıl yeni fikirlere ve kavramlara açık olduğunu göstermeye çalışırken aslında bu yeni alanda karşılaştığı sorunları vurgulamayı ve bu sorunlara çözüm önermeyi amaçlar. Bu haliyle, toplumsal dönüşüm ve değişimleri mevcut kavramlar ile anlamaya çalışmanın kısıtları göze çarpar ki bu makale, KPE literatürü üzerinden bu kısıtları tartışır. KPE içerisindeki kuramsal tartışmaları ele alırken bu makale milieu kavramı üzerinden öneriler sunarak bu tartışmalara katkı sağlamayı hedefler. Makale, KPE araştırma programının bir analizini yaparken buna istinaden de öneriler sunar.

Makale, kentsel politik ekoloji araştırma programının farklı kuramsal okumalar, farklı sorun alanları ve farklı kavramsallaştırma biçimleri çerçevesinde inceler. Daha sonra son 15 yıllık süreyi kapsayan bu yeni literatür içerisindeki kuramsal tartışmaların irdeler. Son olarak bu tartışmalara bir çözüm olarak milieu (kentsel ortam) kavramının tartışmaya açılmasını içerir. Bu çalışma kuramsal bir tartışma içerdiği için yöntem olarak ikincil kaynaklara dayalı bir araştırma metodolojisi izler.

\section{Kentsel Politik Ekoloji: Farklı Kuramsal Okumalar}

\footnotetext{
${ }^{4}$ Foucault' da, aparat (apparatus) olarak ifade edilen, davranış, kurum, milieu, rejim, diyagram ve yönetimsellik, Deleuze' da, Sınırlı düşünceyi, en azından arzu, bölge, felsefe, bedenler ve hareketler açısından parçalamak amacıyla, assamblaj kavramına bürünür (Legg, 2011). Latour (2009) ise, kolektif (collective) ifadesini insan ve insan-olmayan unsurların eşdeğerliğinden bahsederken kullanır. Ayrıca, Deleuze-Althusser içkinlik ve yapısalcılık üzerine derinlemesine bir tartışma için Bkz: Karaman, 2012.
} 
KPE araştırma programı, Marksizim, post-humanizm, antropoloji ve sosyal ağlar gibi farklı kuramsal okumalardan ortaya çıkar. Nik Heynen, Maria Kaika, ve Erik Swyngedouw, 2006 yılında, Kentsel Politik Ekoloji adı altında bir araştırma programı tasarlarken bunu 10 maddelik bir manifesto ile detaylandirırlar (Heynen, Kaika ve Swyngedouw, 2006, s.11-12).

Nik Heynen (2014), kentsel politik ekolojinin iki dalgasını teşhis eder: (1) Marksist yaklaşımlar üzerinden üretim ve kent doğasının anlamı tartışmaları yer alır; (2) Bu yaklaşımlara eleştirel yaklaşan aktör-ağ teorisi, post-insancıllık ile Swyngedouw'ın kullandığı daha geniş teorik çerçeveler yer alır. Yine, bu dalgada, şehirden küresel kent kavramına geçiş kavramsallaştırarak kent ve kentleşme ile sınırlı olmayan daha geniş bir metodolojik alandan bahsedilir. KPE, Neil Smith ve David Harvey önderliğindeki neo-Marksist ve yapısalcı yaklaşımın post-hümanist yaklaşımlara göz kırpan bir kuramsal temelde oturur. Ayrıca, doğa bilimlerinde doğanın failliğinin göz ardı edilmesi tartışmaya açlır. Buna göre, politik ekolojinin nesnesinin ne olduğu sorusu sorulur (Zimmer, 2010, s.345).

KPE, sosyo-ekolojik süreçlerin incelenmesine dair bir araştırma programı önerirken, nesnelerin hibrit biçimi ve insan ile insan-olmayanların eş-üretim süreçlerinin incelenmesine işaret eder. Sosyo-ekolojik süreçlerde araştırılması öne sürülen alanlar arasında (Kaika ve Swyngedouw, 2011): kentsel metabolizmalar, kentsel çevrenin neoliberalleşmesi, kentsel sosyo-ekolojik hareketler ve protestolar ile kentsel çevresel tezahürler ve söylemsel biçimler yer alır. Bu noktadaki bir amaç da araştırma gündeminde kentleri, siborg şehirler olarak kavramsallaştırmaktır. Böylece, insanlar ve insan olmayan unsurları içerisine katarak bunların nasıl "hem mümkün kılan hem de engelleyen bir biçimde" siyaset ürettiklerini incelerken demokratikleşmeye yönelik "politik bir platform oluşturmaya" çalışır (Swyngedouw, Kaika ve Heynen, 2006, s.10).

Erik Swyngedouw (1996), henüz KPE adlandırması olmadan bu literatürün temel okumalarına ve sorunsallarına işaret eder. Swyngedouw (1996), bir bardak su metaforu ile anlatmaya çalıştığı sosyo-ekolojik süreçler üzerinden öne sürdüğü bu araştırma programının teorik çerçevesini materyalist yaklaşım ile anlatmaya başlar. Marx'in toplumsal gelişimin doğal temellerini irdelerken doğanın toplumsal hayatın temel metabolizmasını oluşturduğu fikrine atıf yapar. Bu noktada, Marksist perspektifte, sosyal ilişkiler, yeni sosyodoğal biçimlerin üretildiği doğal çevrede "metabolize edilerek" işler (s. 4). Swyngedouw (1996), Markist perspektifi, doğal süreçleri emek ve toplum ilişkileri dışındaki süreçler olarak görmesini eleştirir. Neil Smith (1984)'e 
atıfta bulunarak üretim süreçlerinde doğanın bütünleştirici rolüne işaret eder ve buradan Lefebvre'ye geçiş yapar. Doğanın bizzat tarihi-coğrafi bir süreç olarak doğanın toplumdan ayrılamayacağına ve bu sosyo-doğa birliğinin üretilen bir şey olduğuna vurgu yaparken hem materyal hem de söylemsel ve sembolik temsiliyetlerin eş-süreçlerine işaret eder (Lefebvre, 1991). Bu noktada işaret ettiği "çelişki" ise, doğanın sosyal olarak üretilen bir unsur olarak görülmesinin bir tür determinizm yaratmasıdır. Bu sebeple, doğal süreçlerin salt sosyal olarak üretilebilen, kontrol edilebilen ve yönetilebilir olduğu fikrine karşı gelir ve bu süreçlerin edilgen değil etken süreçlere olarak birbirlerini karşılıklı etkilediklerini vurgular (Swyngedouw, 1996, s. 5).

David Harvey ve Neil Smith gibi Marksist okumalar çerçevesinde kentin çevresinde ve kentleşme süreçlerinde eşitsizliklere işaret edilir (Swyngedouw ve Heynen, 2003, s.906). Burada, sosyo-doğal süreçlerin kavramsallaştırılması sorunu tartışılırken Marksist materyalist bağlamdan dışarı çıkılamayacağı vurgulanır ve Bruno Latour'a da atfen insan-dışı varlıkların önemine işaret edilir. Bu sebeple, Michel Callon, ve John Law tarafından geliştirilen ve toplumsal süreçlerde insan ve insan dışı varlıkları ayırmayan ve hibrit ağların önemini vurgulayan aktör-ağ teorisi, KPE literatüründeki Marksist yaklaşımları da etkiler (Swyngedouw, 1996). Yine, KPE çalışmalarına etnografik ve antropolojik perspektiften katkı sağlayan çalışmalar da mevcuttur (Cornea, Véron ve Zimmer, 2017). Ayrıca, kentlerin çeperlerine ve kenti doğasına atfeden çalışmalar, doğal kaynakların kenti besleyen ve aynı zamanda dönüştüren ağsal süreçlerine işaret eder. Örneğin, su tüketim ve dağıtımı (Swyngedouw, 1997); atık yönetimi (Demaria ve Schindler, 2016); kentsel dönüşüm (Özberk, 2017); soylulaştırma (Adanal1, 2011) gündelik yaşam ve siyaset (Aksümer ve Yücel, 2018); kentin edimsel, söylemsel ve rastlantısal süreçleri (Samec ve Gibas, 2018) vb.

Bir grup araştırmacı ise kent-çevresi, kentin doğası ve politik ekoloji üzerine inceleme yaparken geniş çerçevede kentsel politik ekolojinin altıda kent çevresindeki doğal kaynakların dağıtımı, iktidar ve siyaset ilişkileri ve alanları üzerine incelemeler sunar (Karpouzoglou, Marshall ve Mehta, 2018). Kentsel politik ekoloji içerisinde, kentlerde doğanın ekosistem hizmetleri içerisinde nasıl kullanıldığında ve tüketildiğine odaklanırken (Liu, vd., 2010) bu hizmetlerin sosyo-ekonomik ve politik faktörler ile insan faktörünün göz önüne alınması gerektiğini vurgular (Depietri, vd., 2016). Bu açıdan kontrol ve denetimin farklı mikro siyaset biçimleri irdelenir (Truelove, 2011, s. 145). Kentsel politik ekoloji ile Bilim ve Teknoloji Çalışmalarının (Science, Techno- 
logy Studies) etkileşim noktasını inceler. Örneğin, bazı araştırmacılar haritalandırma uzmanlığının toplumsallık ve politik süreçlerden bağımsız olamayacağını tartışırlar. Kritik haritalandırma ile seller önlenebilir sorusuna salt haritalandırmanın bunda yetersiz olduğu yanıtını verir ve yerel epistemik siyasetin rolüne işaret ederler (Gustafson, 2015). Böylelikle, KPE, kavramsal çerçevede politik ekonomi, politik ekoloji ve Bilim ve Teknoloji Çalışmaları gibi birçok alanı kapsayan bir alan olarak görülür (Heynen, 2014, s.599).

\section{Sorun Alanlarn}

KPE literatürünün çıkış ve başlangıç noktası farklı sorun alanları ve sorunsallarla ilişkilidir. Bunlar arasında metodolojik çelişkiler; kent-doğa ayrımı sorunsall; eşitsiz gelişme ve dolayısıyla artan küreselleşme ve kapitalizm; güç ve iktidarın kavramsallaştırılması; faillik; değişim ve dönüşüm dinamikleri; ile sürdürülebilirlik yer alır. Her ne kadar her bir sorunsal kendi içinde derin ve çeşitli literatür ve kuramsal bağlar barındırsa da doğa-kent ayrımı sorunsalı KPE literatürünün bir tür oluşturucu sorunsal olduğu söylenebilir.

KPE literatürünün de her defasında vurgulamaya çalıştığı şudur: Latour'un (2004) ifadesiyle, "ne nesneler doğaya aittir ne de özneler topluma aittir" (s. 90). KPE literatürünün tartışmaya açtığı, kentleşme süreçlerinde doğa-toplum, doğa-kent ve kent-kır ayrımlarının ortadan kalkmasıdır. Bu anlamda kentsel politik ekoloji, doğa ve toplum ikilemine farklı bir bakış açısı getirir ve her ikisinin de kendi öz varlığı süreçlerinin olduğu fakat toplumdoğa ile birlikte toplum ve doğanın da eş-oluşum süreçleri yarattığını vurgular. Bir başka deyişle, kendi saf süreçleri içerisinde devam eden yaşamları aynı zamanda birbiri ile de etkileşim içerisindedir. Hem şehrin doğasını hem de doğanın şehrini dönüştüren, çekişen ve yöneten bir etkileşimden bahsederken tam metabolizma metaforunu kullanır (Swyngedouw, 1996, s. 7; Candan ve Kolluoğlu, 2015; Erensu, 2015). Bunu yaparken iki unsura da eşit oranda yaklaşır. Bu sosyo-doğal oluşturma süreçlerindeki eşitsiz konfigürasyonlar tam da kentsel politik ekolojinin çalışma alanıdır. Kentsel ve doğal ortamlar arasındaki kentsel toplumsal süreçler ile politika içindeki ikilikleri ve sinırları deşer (Heynen, 2014, s. 600).

Şehirleri (kültürel ve toplumsal boyutu da dahil) doğanin tersi olarak alg-layan, salt insan aktivitelerinin yerleşimi olarak gören yaklaşımları eleştiren KPE doğa-kültür ve dolayısıyla doğa-şehir ayrımını modernitenin getirdiği ayrım olarak görür ve buna karşı çıkar (Soens, vd. 2019; Özberk, 2017). Politikalardan ziyade politika yapım süreçleri ve bunların aç九tğı siyaset alanlarına 
odaklanarak aktörlerin kim olduğunu sorar ve bunlar arasındaki etkileşimi inceler. Ayrıca, ekolojik ve toplumsal süreçleri zedeleyen kentleşme pratiklerini irdelerken (Coates, 2019); yeniden-kentleşme ve yeniden-kırsallaşma süreçleri arasındaki diyalektiğe işaret eder (Rice ve Tyner, 2017). Doğanın kentselleşmesi ve eşitsiz coğrafi gelişme eleştirilirken bu metabolizmalar güçlü birey ve grupları mümkün kıldığı, marjinal grupları devre dışı etkisiz bıraktığı bir seri toplumsal ve çevresel koşullar yarattı̆̆ dile getirilir (Swyngedouw ve Heynen, 2003). KPE, Lefebvre'nin gezengensel kentleşme teorisinde belirttiği, kentleşmenin zamanla kentsel ve kırsal mekân ayrımlarını ortadan kaldıracağı öngörüsünün peşinden gider (Öztürk, Hilton ve Jongerden, 2014).

KPE, literatüründe birçok sefer atfedilen, David Harvey'nin (1996) “New York'ta doğal olmayan hiçbir şey yok" (s. 186) ifadesi KPE'nin temel çıkış sorunsalıdır. David Harvey ve Neil Smith ile Marksist teorilerin etkisinde, kentin ve mekânın eşitsiz ve adil olmayan şekilde gelişimi ve üretimini irdeler. Buna göre, KPE, mekânın çevre, insan ve siyaset ile ilişkisinin imkanlarını ve kısıtlarını teşhis eden bir alan olarak çok geniş bir referans noktasına sahiptir. Harvey (1996; 2009), doğa, çevre ve toplumsalın eş-meydana gelme süreçleri içerisinde toplumsal ilişkilerin oluşturucu ve yapılandırıcı biçimleri sonucu oluştuğunu, şekillendiğini ve yeniden biçimlendiğini ifade eder. Bu eş meydana gelme kentsel mekânda kapitalist ilişkilerin üretildiğine ve bu üretimin karşılıklı hem toplumsal ilişkilerin hem de mekânın ve çevrenin üretimine işaret eder. Bu anlamda, mekân, çevre, doğa, bağlantılar ve ilişkilerin birbirinden ayrı oluşum süreçleri olmadığını, birbiri ile ilişkili olduğunu dile getirir. Sosyal ilişkilerin çevresel ve mekânsal dönüşüme gömülü olduğunu vurgularken bir kentin inşasında bu gömülü ilişkinin hem doğa hem de toplumsalı inşa ederken doğa ve toplumun birbirinde ayrı olmayan bir tezahürü olarak kentin inşasını anlatır. Bu gömülü ilişkilerde, insanın bedeni, ihtiyaçlarının doğal unsurlar olduğunu vurgularken ruh-beden, akıl-ruh ikilemlerinin bilişsellik ile birlikte insanın faaliyetleri ve sosyal ilişkilerin doğal bir ürünü olduğunu anlatır. Burada doğa/çevre sosyal insan ve sosyal ilişkilerce üretilen bir alandir.

Kentsel mekânın bu şekildeki bir tezahürü, o alanda ortaya çıkan kapitalist ilişkilerin, güç ilişkilerinin, dengelerin, pazarlıkların ve çıkar ilişkilerin incelenmesine imkân verir. Burada kim hangisinden nasıl ve ne sebeple daha çok kazanç elde etti, rant sağladı, bunların açı̆̆a çıkmasını sağlar. Burada, kurumlar ve mikro iktidar ilişkilerinin ortaya çıkarılabilmesine bir altlık da oluştuğu söylenebilir. Zira, salt kapitalist ya da salt kurumsal ilişkilerin ötesinde 
mikro iktidar ilişkilerinin kentsel mekânı ve çevreyi nasıl dönüştürdüğü, kimin ne elde ettiği, hangi iktidar teknolojileri ile bu kazanımın sağlandığı, konfigürasyonların nasıl değiştiği ve bunların nasıl farklı biçimlerde yeninden yerinde üretildiği de sorgulanabilir. Örneğin, değiş-tokuş ilişkilerinden kimin daha çok elde ettiği sorusunun ötesinde bu ilişkinin nasıl ortaya çıktığını, nasıl dönüştügüü, bu ilişkinin kentsel mekânı nasıl mümkün kılan bir araç haline getirdiğini ve bunun da başka mümkün kılınabilen ilişkiler ürettiğinin teşhisi Harvey'nin bahsettiği doğa ve toplumsallık arasındaki eş oluşum süreçlerinin incelenmesi ile ortaya çıkabilir.

Kentsel kaynakların eşitsiz dağıtımı, kullanımı, dolaşımı, ve bunların toplumsal ilişkiler üzerinden eleştirisini içerir. Bunlar arasında, alan kullanımı, suyun dağılımı, enerji ve gıda kaynakları yer alabilir (Heynen, Kaika, ve Swyngedouw 2006; Heynen, 2006). Yine, bu süreçlerdeki karar alma mekanizmaları ve yapıları incelenirken kimlerin kazandığına kimlerin kaybettiğine kimlerin zarar gördüğünü inceler. Bunu yaparken de kimin neye ihtiyac1 olduğunu ve bu ihtiyaçların nasıl sürdürülebilir olacağını dile getirir. Bu anlamda, sınıf, etnik kimlik, toplumsal cinsiyet ve güç mücadeleleri alanları üzerine gider. Sosyal gücün geometrisinin varlı̆̆ pısalcı analiz sunan KPE, bu geometrinin süreç bazlı bir incelemeyle açığa çıkarılabileceğini ve bu şekilde toplumsal çatışmalar ve politik ekonomik mücadelelerin anlaşlabileceğini söyler (Swyngedouw ve Heynen, 2003, s. 901).

İktisadi ve siyasi gücün kaynakların tahsisi, kullanımı ve dağılımı süreçlerindeki rolüne işaret eder. Metalaştırma, özelleştirme, kentsel krizler, altyapı inşası ve altyapı problemleri, gıda sorunları, kentsel dönüşüm, bulaşı1 hastalıklar, kentlerin sürdürülebilirliklerinin kentin doğası ile olan bağlı olma süreçlerinin kara kutularını açar (Swyngedouw 1997; Monstadt, 2009). Bunu yaparken de "kentsel yaşamı destekleyen ve koruyan sayısız dönüşüm ve metabolizma" tanimlar (Swyngedouw ve Heynen, 2003, s.899). Yapisalcı ve tözcü yaklaşımlar tarafından kapitalist gelişmenin ve modernitenin bir nesnesi olarak görülen doğa ve kentin farklı tezahürlerinin incelenmesi ve bunların çetrefilli olmasının tartışmaya açılmasına sebep olur. Buna göre, "şehrin doğası - hem sosyal hem de fiziksel - doğanın kentleşmesinin tarihsel-coğrafi bir sürecinin sonucudur" (Swyngedouw ve Kaika, 2000, alıntı: Swyngedouw ve Heynen, 2003, s.900). Değişim, dönüşüm ve toplumsal olayların anlaşılması ve kent ile doğayı oluşturan unsurların sosyal olarak oluşturulması, sosyal olarak harekete geçirilmiş ve sosyal olarak yetkilendirilmiş güç ve iktidar ilişkilerinin irdelenmesini mümkün kılar (s. 902) 


\section{KPE ve Kenti Kavramsallaştırma Biçimleri}

David Harvey (1973), kenti, "açıkça karmaşık bir şey"5 (s. 22) olarak tanımlarken kenti kavramsallaştırma sorunsalına işaret eder. Kaika ve Swyngedouw (2011), kenti “kolektif olarak üretilen sosyo-doğal eserlerin bir külliyat" olarak tanımlarken Swyngedouw ve Heynen, (2003), "zaman ve mekân içerisinde süregelen metabolizma" olarak kenti kavramsallaştırır. Bu metabolizma oluşum ve devamlılığ sürecinin "bitimsiz ve sürekli devam eden anlar" içerdiğini söylerken ölçek sorununa değinilir (s. 912). Fakat bu, bir "coğrafi ölçek" değil, "belirli sosyal ve çevresel ölçeklerin oluşturulduğu ve daha sonra yeniden oluşturulduğu sosyo-ekolojik süreçtir" (s. 914).

KPE içerisinde kent ve kentsel mekânın kavramsallaştırılması farklılık gösterse de birincil çıkış noktası kentin siborg ve metabolizma olarak görülmesidir. KPE, güç dengesizliklerinin temsiliyet, söylem, ideoloji, materyal ve biyo-kimysal kümelenmesini "kentsel metabolizma" kavramı ile inceler. Metabolizma, bir metafordan öte, şekillendirilmiş/gömülü siyaset olarak anlamlandırılır (Doshi, 2017). Swyngedouw (1996) kentsel politik ekoloji araştırma programın öne sürerken salt toplumsallıktan ya da salt teknikten ve salt kurgudan bahsedemeyeceğini sorunsallaştırır. Bunu yaparken de kentlerin şehir ve kentsel süreçlerin insani, doğal, gerçek ve kurgusal, mekanik ve organik yönlerinin olduğunu vurgular. Bu yönlerin ise, birbiriyle hem iç içe geçen ve bütünleşik hem de birbirleriyle huzursuz, çelişkili ve gerilimli bir ilişki halinde olduğunu vurgular (s. 2). Burada şehir, "hibrit sosyo-doğal şey” olarak ifade edilirken sosyo-ekolojik süreçlere işaret edilir (s.2).

$\mathrm{Bu}$ Marksist materyalizminden gelen bir altyapısal fikirdir. Metabolizma kavramsallaştırması ile kentlerin toplumsallıkla harekete geçirilen doğal süreçlerce, doğal kaynaklar tarafından inşa edildiği ifade edilir. KPE literatürünün, Lefebvre (1976)'den canlandırdığı argümanı, "ikinci doğa" dır ve kentsel çevrenin toplumsal üretimine odaklanılır. Buna göre, ikinci doğa, kentleşme sürecinde "doğanın yıkılması ve başka bir seviyede yeniden inşasıdır" (s. 15). Böylesine bir metabolizma kavramsallaştırmasında, toplumsal süreçler, materyal metabolizma ve mekânsal biçim iç içe geçer. Metabolizmanın kendini beslediği ve kendi içerisindeki sorunları, yeni alanları ve formları yeniden ürettiği süreçler tartışmaya açlır. Swyngedouw (1996), metabolik kentleşmeyi anlatırken siborg kentlerin inşasını da bir tür eş-oluşum süreci olarak anlatır ve bunu materyal dolaşım süreçleri (örneğin, su, gıda, arabalar, para, vb.) üzerinden ifade eder. Örneğin, kente gelen ve kent içinde dolaşıma giren

\footnotetext{
${ }^{5}$ Orijinal cümle: "The city is manifestly a complicated city".
} 
elektrik enerjisinin ve suyun yarattı̆̆ çetrefilli politik ve siyasi alanlar incelenir (Usher, 2014). Nature's Metropolis (Doğa'nın Metropolü) adlı kitabı ile William Cronon anlatmaya çalıştığı, doğanın kentleşmesinin nasıl huzursuz müdahale alanları yarattığıdır.

"Kentin bir siborg olarak üretimi, hibrit su sirkülasyonunun analizi yoluyla kazılan, kent üzerinde düşünmek ve hareket etmek için yeni bir arena açar; ne yerel ne de küresel olan, ancak her zaman ayn anda derinden lokalize olan ve belli bir mekansal yüzey olan belirli bir ölçekte erişimini genişleten bir ağı ören bir arena. Vücuda, şehre, bölgeye ve dünyaya suyla akan gerilimler, çatışmalar ve kuvvetler çatlaklardaki çizgileri, ağlarm örgülerini, direnç ve iktidar alanlarmı ve platolarmn gösterir" (Swyngedouw, 1996, s. 18).

Böylesine bir kavramsallaştırmada, metabolizma ve dolaşım süreçleri sorunsallaştırılır. Metabolizma, Donna Haraway'in siborg (2013) ve Bruno Latour'un (2009) yarı-nesne kavramlarına atfen kentin hibrit konfigürasyonlarına da işaret eder ve kentler bir parça toplumsal, bir parça doğal olan oluşumlar olarak incelenir (Demaria ve Schindler, 2016). Bu oluşum süreçlerindeki eşitsiz ve adil olmayan uygulamalar eleştirilir (McKinnon, vd., 2017).

Swyngedouw (2006) kenti "bir bütün olarak, insan/insan olmayan gömülü yapıların bir sosyo-fiziksel birikimi" olarak görür (s. 25). Bu anlamda, metabolizma ve dolaşım kavramları temelinde bir kavrayış söz konusudur. Richard Peet ve Michael Watts (2000) tarafından hibrit ve sosyal yapılandırmacılık kavramları doğanın sabit kategorisine karşı geliştirilir (alıntı: Angelo ve Wachsmuth, 2015). Doğa ve toplum etkileşiminde iktidar, güç ilişkileri ve siyaset alanlarına, doğanın ve toplumun idarî düzen altına alınmasına odaklı bir politik ekoloji yaklaşımı olarak değerlendirilebilir (Özberk, 2017, s. 202). Kentsel politik ekoloji tartışması kentlerin hibrit oluşumlar olarak görülmesi yaklaşımı ile canlanır (Swyngedouw, 1996). Bu açıdan KPE doğanın ve toplumun içe içeliği nesnelerin de bu süreçteki yerinin birlikte ele alınması gerektiğini dile getirir. Bu hibrit oluşum fiziksel materyal olan; pratik ve meta olan; söylemsel ve yapılandırmacı olan unsurları işaret eder (s.6).

KPE içerisinde, kentler yönetimsellik sorunu etrafında da kavramsallaştırılır. Gabriel (2014), kentin yönetilebilen bir alan olarak görülmesi ve yönetimsel ve altyapıya ilişkin unsurların bitimsizce tartışılması istenir.

"Kentsel ekolojik araştırma ve uygulamalarla politik olarak ilgilenmek, şeylerin ve koşullarm algılandığı çerçeveyi değiş̧tirmek, imkânsızlık koşullarmı sadece mümkün olana değil gerekli olanlara dönüştürmekle ilgilidir. Yine, neoliberal bir çerçevenin ötesine geçen kentsel çeore ütopyalarm hayal etmek zorunludur. 
Tekrar denemeye cesaret göstermeliyiz, tekrar düşünmek zorunda kalsak bile, tekrar düşünmek zorundayı" (Kaika ve Swyngedouw, 2011, s.104).

$\mathrm{Bu}$ anlamda, KPE içerisindeki tartışmalar taze ve sıcaktır. KPE, bu yaklaşımı sürekli sınamak, test etmek ve zorlukları ile de başa çıkmak üzere bir anlayışa da sahiptir.

\section{KPE Literatürü İçindeki Kuramsal Tartışmalar}

$\mathrm{KPE}$, kendi içerisinde farklı disiplinler ve kuramsal yaklaşımlar barındırır ve kendi içerisinde tartışmalı, çelişkili ve ikircikli bir durum ortaya çıkarır. Angelo ve Wachsmuth (2015), KPE'nin iki temel amacından (birincisi politik ekolojinin kenti çalışması; ikincisi, kentleşmenin kavramsallaştırılması ve teorize edilmesi) ilkinin gerçekleştĭgini fakat kentleşmenin teorize edilmesinin başarılı olmadığını vurgular. Buradaki sorunsalın kentleşme ve kent kavramlarının Swyngedouw tarafindan aynı anlamlarda kullanılmasıdır oysa biri sonuç diğer ise sürece işaret eder (s. 5). Bu açıdan, KPE'nin, Lefebvre'nin şehircilik yaklaşımını harekete geçirme vaadini yerine getiremediğini de vurgularlar. Onlara göre, kentlerin metodolojik olarak analiz edilmesi anlamlı olabilir fakat bunun metodolojik determinizme götürmesi kısıtlar yaratabilir. Bu şekilde bir determinizm aynı zamanda şehirlerin kentsel analizde yegâne analiz alanı olarak rasyonalize edilip doğallaştırıldığı eleştirilir. Bu açıdan sosyo-doğal süreç analizine dayanan araştırma programının ampirik incelemeler ile paralellik göstermemesi ve tutarlı olmaması vurgulanır (Angelo ve Wachsmuth, 2015).

Kentsel politik ekolojide, şehre ait olan unsurların dönüşümünün, dolaşımının, dağıtımının ve metabolizmasının toplumsal ve doğal olan ile ilişkisinin araştırılması, kent dışındakinin "sessizliğe" gömülmesi olarak düşünülür (Angelo ve Wachsmuth, 2015, s. 21). Bu açıdan yerelin, kent çeperleri, kent merkezi dışından ve sınırlar ötesinden gelen unsurların da analizi önemlidir, örneğin, nükleer santraller, teknoloji ile zaman ve mekân sınırlarının ötesinde kalan unsurlar vb. Ayrıca, bu eleştirilerde şehirlerin ne şekilde doğal kaldığı, onların nasıl kente dönüştüğü veya kent tezahürünün nasıl oluştuğu yanıtsız kalır (Angelo ve Wachsmuth, 2015). Bu anlamda, Swyngedouw'ın Lefebvre izinde ortaya koyduğu ayrımlar sonraki çalışmalarda da yer almaz.

Bu eleştiriler 1şığında, Angelo ve Wachsmuth (2015), kent değil, kentleşmenin politik ekolojisi yaklaşımını önerirler. Angelo ve Wachsmuth (2015)'e göre, kentsel politik ekolojinin ilk dönemlerinde yapmak istediği "kentleşmeyi küresel bir süreç olarak keşfederek, kent / kırsal ve toplum / doğa ara- 
sındaki geleneksel ayrımların ötesinde Lefebvre'nin teorik çerçevesini harekete geçirmek[tir]", fakat KPE'nin Lefebvre'nin izinden gidemediğini vurgularlar (s. 16). KPE'nin metodolojik şehircilik yaklaşımı olarak - geleneksel şehir üzerinde ezici bir analitik ve ampirik odaklanma - (s. 16) olarak bahsedilen süreçte çağdaş kentleşme süreçlerinin farklı ve karanlıkta kalan yönlerinin dışlanması ile açmaza girdiği düşünülür. Buna göre, KPE, bir Lefebvre eleştirisi üzerinden, kentleşmenin politik ekolojisinden ziyade salt kentlerin politik ekolojisine odaklanmıştır. Politik bir metodoloji geliştirememesi de Roger Keil (2005) tarafından dile getirilir ve KPE'nin kentsel doğa için yeni bir politik metodoloji tanımlayamaması eleştirilir.

KPE, her ne kadar, doğa-kent ikilemini sorunsallaştırma üzerine kurulu bir araştırma programı olsa da bu noktada ne kadar radikal olduklarını her fırsatta tahlil etme ihtiyacı içerisinde olurlar. Bu açıdan da kendi içerisinde tartışma halindedir. Kent-doğa ayrımını yıkma çabasında sınır tanımadan ilerleme gayretini öne sürerler (McKinnon, vd., 2017), örneğin göç, soylulaştırma, Küresel Güney, gıda (Keil, 2003; 2005; 2011) vb. ${ }^{6}$. Bu bağlamda, Arboleda (2016), en acımasız eleştirileri yönlendirir ve KPE'nin geniş toplumsal boyutları keşfedemediğini (Angelo ve Wachsmuth, 2015) ve "kentsel aglomerasyonların ötesine geçilemediğini" söyler (Arboleda, 2016, s. 99).

Eleştirel bir yaklaşım ile 'kent teorisinde' kentsel olanın ne olduğu sorusu soran Roy (2016), Dipesh Chakrabarty'nin Avrupa'yı Taşralaştırmak kitabına atıfla, taşranın sermayeleşmesi ve kırsalın çoğaldığına işaret ederek Batı-dışı kentleşme pratiklerinin kent olgusunu nasıl yeniden tasavvur edeceğini sorgular. Post-kolonyel toplumlarda kentin ne dereceye kadar kent olarak düşünülebileceğini sorunsallaştırır. $\mathrm{Bu}$ eleştirinin devamında,

\footnotetext{
${ }^{6}$ Heynen (2016), 3 makalede İlerleme Raporu KPE'nin gelişimini ve olası araştırma alanlarını anlatır. İkinci makalesinde, kentsel politik ekoloji çalışmalarında cinsiyet ve eşit ve adil olmayan sosyal ilişkilere de odaklanılmasını önerir (McEntee, 2014). Heynen (2018), üçüncü makalesinde feminist ve dezavantajlı gruplar üzerinden daha eşitlikçi politik olasılıklar açısından KPE tartışması yaratır. Bu tartışmayı kent metabolizmasındaki değişimleri incelemek üzere tasarlar ve ev, akrabalık, aile ilişkileri, tüketim, atık ve kaynak dağılımı üzerinden tartışmaları önerir. Benzer şekilde, Doshi (2017) feminist, 1rkçılık-karşıtı ve post-kolonyal yaklaşımlara yönelik geçmiş yapısalcı tezahürleri eleştirel biçimde beşöneri sunar. Bunlar, metabolizma, sosyal üreme, kesişme ve eklemlenme, duygu ve tesir, politik öznellik. Bu önerilerdeki temel prensip beden üzerinden bir düşünce geliştirmesidir. Keil (2005), KPE literatürünün yine ilerleme raporu adı altında kaleme aldığı makalesinde KPE'nin, gıda ve Küresel Güney ile ilgili daha çok ampirik çalışma yapılmasını önerir. Yine, çalışmaların daha siyasi ve siyaseten etkiler üzerine düşünmesi gerektiğini öne sürer. KPE literatürü içerisinde siyasi metodoloji geliştirmemesi eleştirilir (Whitehead, 2005).
} 
Lawhon, Ernstson ve Silver (2014), farklı kent tezahürlerinin Batı-dışı biçimlerinin araştırılması gerektiğini savunurken "konumlandırılmış KPE" ifadesini kullanırlar. Buna göre, analiz birimi için gündelik hayata odaklanmayı önerirler ve geleneksel KPE' deki akış ve hareketlilikler ile sistemik değişim yerine iktidarın yayılma biçimleri ve politika oluşturmada radikal ilerlemeyi önerirler (s. 506). Yine, Eckers ve Loftus (2008), Foucault ve Gramsci okuması üzerinden iktidarın davranışı yöneten bir yapısal alan olarak düşünülmesini eleştirir ve iktidarın merkezsizleştirilmesi gerektiğini düşünerek sosyo-doğal ilişkilere işaret eder (s.700).

$\mathrm{KPE}$, antroposen yaklaşımları kesin bir çizgiyle reddeder. İnsan hayatının çevresindeki doğal koşullarla iç içe olması ve Zizek'in (2012) "hayatta kalma tarzımız kolektif aklımızın olgunluğuna bağlı" yaklaşımının tam tersi insanların başka türlere hâkim olma sürecinde kuvvet statüsü kazanmış oldukları[n]" savunan antroposen yaklaşımlar da sert biçimde eleştirilir (s. 33).

Bu bölümde anlatılan KPE içerisindeki sorunlar şu şekilde özetlenebilir: (1) Ampirik bulgular ile teorik kavramlar arasındaki tutarsızlık; (2) Analiz biriminin sınırlarının çizilememesi; (3) Metodolojik determinizm sorunu; (4) Akış ve değişimleri takip etmekteki zorluklar; (5) İkilemler (doğa-insannesne) içerisinde kalmak. KPE literatürünün kendi içerisindeki bu tartışmalar bir sonraki bölümde önerilecek milieu kavramının tohumlarını da ekmektedir aslinda.

\section{Milieu Kavramı}

Deleuze ve Guattari (1937), milieu ve ritimlerin kaostan doğduğunu söyler. Ritimlerin birbirlerini sürekli olarak dönüştüren ve değiştiren birçok milieu arasında meydana geldiğini öne sürerken ritimlerin toprak, bölge ve il/taşra ile ilintili olduğunu dile getirir (s. 313). Milieu'lerin ise periyodik tekrarlama ile kodlandığı fakat bu tekrarların metrik kadar kesin ve statik olmadığı; milieu'ler değiştikçe, birleştikçe ve eklemlendikçe sürekli dönüştüğü, farklılaştığı ve değiştiğini dile getirir. Bu anlamda, milieu fiziksel mekânın ötesindeki ilişkisel dinamikleri, olasılıkları ve rastlantısallıkları ortaya çıkaracak bir analiz alanına işaret eder. Kentlerin karmaşıklık ve çoğullukları göz önüne alındığında ise, "Simond'un ilişik milieu" ifadesi ile "nesnelerin ve durumların birlikte oluşumunu ve birlikte ortaya çıkmasını belirten bir yol olarak" milieu kavramı harekete geçirilmeye çalışılır (Venn ve Terranova, 2009, s.10).

Foucault'ya göre, milieu, "üzerinde çalışan ve sırayla üzerinde çalıştıkları bir dizi maddi unsurla birlikte çalışan ve birlikte yaşayan çok sayıda birey 
arasındaki kesişimi" dir (Foucault, 2009, s. 36). Bir tür müdahale ve ilişkilerin kontrol alanı olarak milieu' nün iktidar tarafından dolaşım ve nedensellik arasındaki ilişkileri güvenlik rejimi içerisinde tartışılır (Foucault, 2009, s.21). Milieu, problem ve müdahale alanı olarak kent ve şehirle bağdaştırılır ve "dünyalaşan kentin müdahale ortamları" olarak tanımlanır (McCann, Roy ve Ward, 2013, s.584; Ovacık Çoruh ve Uluoğlu, 2018; Ovacık Çoruh, 2018). Burada milieu'ler pasif ya da pasif olmayan tanımlarına bürünür (Lewis, 2017; Söderström, vd., 2016).

Oysa, Lefebvre'nin eleştirdiği gibi milieu'ye pasif bir anlam yüklemenin ötesinde milieu'nün edimsel ve mümkün kılan rolü ön plana çıarılabilir ve milieu'lerin ilişkisel, araçsal ve mümkün kılan etmenleri tartışılabilir. Dönüştürülebilir bir alan içerisinde biyo-iktidar tarafından düzenlenmiş bir seri ve mekansal-zamansal belirsizliğin milieu'sü olarak (Johnson, 2008; RoseRedwood, 2012) bu milieu'nün oluşturucu unsurları ortaya çıkarılmalıdır. Teknolojinin gelişmesi ve iletişim ağlarının teknolojiye entegre olması ile birlikte, Terranova (2004) bilgi ve teknolojinin topraksız milieu'lerinden bahsederken yerlerin alanlarından (space of places) ziyade akışların alanlarına (space offlows) işaret eder. Yine piyasa mekanizmasına atıfla - örneğin, mega kentler (Adey, 2013; Ribeiro ve Santos Junior, 2017) - piyasanın kendisinin de soyut milieu haline gelir (Terranova, 2009).

Örneğin, milieu bir yandan piyasayı mümkün kılan ve çevrenin marketize edildiği bir ortam iken bu ortam bir tür "girişim toplumu" olarak işletilme, çoğaltılma ve yayılma pratiklerinin alanı olarak yönetilir (Venn, 2009, s. 211). Kamusal alanların imara açılması ile ortaya çıkan milieu içerisinde mekân ve alanının piyasa aracı olarak kullanması, bu sürede ortaya çıkan belirsizlikler silsilesi ve bunların yönetimi irdelenebilir. Mesela, mega projeler ile değişen regülasyonlar, değişen yönetimler, altyapı sorunları, kurumlar arası iletişimsizlik ve çıkar ilişkileri bir milieu içerisinde varlık gösterir. Projenin yürütülmesi esnasında, örneğin, ortaya çıkan bir tarihi eserin ya da su kanalının nasıl ve hangi kurum tarafından korunacağı, bunun projeye etkisi gibi unsurlar milieu içerisinde çıkan farklı belirsizlik unsurlarıdır. Bu unsurlar milieu'nün zaman içerisinde değişimini gösterdiği gibi yeni milieu'lerin oluşmasına da yol açabilir. Yine, ulaşım özelindeki mega projelerde, milieu'lerin bütünleşik milieu'ler olarak değil de parçalı kurumsal yapıların ürettiği projeler olması ve doğa-insan-nesne ilişkisini kesmesi bağlamında incelenebilir. Yine mesela, deniz-kara-raylı ulaşım alternatiflerinin birbirlerini tamamlayıcı olması gerekirken iktidar ilişkileri içerisinde birleştirici ve bü- 
tüncül faaliyetler yerine rekabetçi unsurların ortaya çıkması bazı ulaşım alternatiflerini geri planda bırakırken bazıların da ön plana çıkarabilir. Bu anlamda, hem karar alma hem de uygulama süreçlerinde milieu yaklaşımı planlama ve politik analiz ölçüsünde bütüncül bir bakış açısı da sunabilir.

\section{KPE ve Milieu Kavramı}

Nik Heynen, Maria Kaika, ve Erik Swyngedouw, 2006 yılında "Şehirlerin Doğasında: Kentsel politik ekoloji ve kentsel metabolizmanın siyaseti" adı altında derledikleri kitabın giriş kısmında kentsel politik ekoloji literatürü olarak adlandırdıkları bir araştırma programını 10 Maddelik bir manifesto ile (Bkz: Ek-2) tartışmaya açtılar. Bu manifestonun ilk maddesinde, çevresel ve toplumsal değişimlerin birbirini eş zamanlı belirledikleri vurgulanırken sosyo-çevresel metabolik dolaşım süreçlerinin hem toplumsal hem de fiziksel çevreleri dönüştürdüğü ayrıca bunların toplumsal ve fiziksel milieu'ler ürettiklerini söylerler. Burada, milieu olarak bahsettikleri "şehirler" dir. Bu literatür milieu'nün üretilen ve içerisinde çelişkiler barındıran bir alan olarak kavramsallaştırmaktadır.

Ayrica, Swyngedouw ve Heynen (2003), makalelerinin bir yerinde geçirdikleri "yerel milieu" ifadesi ölçek bazlı ve skaler bir biçimde yerelden küresele uzanan ilişkilerin mekansal ve yakınlıkla alakalı bir alana işaret ettiğini ifade eder. Fiziksel çevre olarak milieu kavramını kullanan, Crevoisier (2004), yenilikçi milieu'ler adı altında 1980'lerin ortalarında Philippe Aydalot (1986) ve Roberto Camagni (2005) tarafından kavramsallaştırılan terimi iktisadi ilişkilerle sınırlı bir yakınlık ilişkisine bağlar (Malmberg, 1996). Kentin farklı işlevlerin gerçekleştirildiği tarihe eklemlenen karmaşık bir fenomen olarak imgelenmesi ile yerel milieu tanımlanır (Camagni, 2005) ${ }^{7}$.

Fakat milieu kavramı KPE içerisinde genel geçer kabul edilmektedir. Oysa, bu kavramın saklı kalan analiz boyutlarının ortaya çıkarılmaya ihtiyacı vardır. KPE içerisinde tartışılan bu hususlar, milieu ifadesi üzerinden bir kavramsallaştırma ile daha serbest ve özgür bir analiz alanı açabilir. Bu bölüm,

\footnotetext{
${ }^{7}$ İşlem maliyeti teorisinin beslendiği yakınlık, güven, belirsizlik kavramlarına dayanan yenilikçi milieu'ler olarak kavramsallaştırılan yakınlık mekânı ve yerel ilişkilerin toprağı düşünülür. Burada iktisadi ilişkiler ve endüstriyel bağlantılar, firmalar arası yakın mesafeler ön plana çıkar ve bu unsurların öğrenme, yerel süreçler ve yenilikçiliği arttırdığı yeni teknolojilerin gelişmesine ve üretilmesine sebep olduğu düşünülür ki yenilikçi milieu ifadesi buna dayanır (Malmberg, 1996). Ayrıca, firmaları, müşterileri, araştırma kurumlarını, okul sistemini ve yerel yetkilileri bağlayan milieu eklemleri (milieu linkages, Camagni, 2005, s.125) belirli bir maddi (firmalar, altyapı), maddi olmayan (bilgi, teknik bilgi) ve kurumsal (otoriteler, yasal çerçeve) unsurlar ile karakterize edilir (s.397).
} 
milieu kavramının KPE içerisindeki tartışmalara iki acıdan çözüm getirebileceğini tartışmaya açar: (1) Fiziksel sınırlar yerine ilişkiler sistemi; (2) Metodolojik şehircilik yerine olasılıklar ve rastlantısallıklar.

1. Fiziksel Sınırlar Yerine İlişkiler Sistemi: Milieu kavramı mekân, karmaşıklık ve ilişkisel dinamikler üzerinden ele alınır. Georges Canguilhem (2001), milieu kelimesini bir yaşam çevresi olarak düşünür (s. 25). Amin ve Thrift'in (2002) bahsettiği, akışlar ve akışkanlar bireyler ve nesneler arasındaki etkileşimin bir aracı olur. Bu etkileşimin soyutlaştırıldığı akışkanlar ifadesi bir aracı rolü üstlenir ve bu akışkanlıklar üzerinden milieu ifadesi kullanılır. López-Durán ve Moore (2018), milieu kavramını alanı ve toplumu rastlantısallık hallerinde bir araya getiren ilişkisel bir sistem olarak ele alır. Sınırlar yerine düzlem ve ilişkiler sistemi tartışlır (Canguilhem, 2001):

"Milieu" teriminin başarısında, çizginin metaforu veya süresiz olarak genişletilebilir düzlem, hem sürekli hem de homojen olan, kesin bir şekli veya ayrtcalkkl bir konumu olmayan, küre veya dairenin metaforu üzerinde, yine de şekilleri kazanır. Milieu gerçekten desteksiz, safbir ilişkiler sistemidir. Milieu, unsurlarm ve eorensel hareketlerin anonimliğindeki bireyselleştirilmiş organik sentezin çözünmesinin evrensel bir aracı haline gelir" (s. 11).

Akışlar üzerinden bu analiz KPE'nin kent-doğa ayrımı üzerindeki tartışmaların kolaylaştırılmasını sağlar zira davranışsal, coğrafi ve fiziki milieu arasındaki bağlantıların ayrılması milieu kavramsallaştırmasında söz konusu değildir (Canguilhem, 2001, s. 15). Örneğin, çizgilerle sinırlandırılmış kent haritaları artık anlamını yitirmeye başlamıştır. Zira coğrafi ve fiziksel sınırlar doğal olanın ve doğa-nesne-insan etkileşimlerinin yarattığı karmaşık konfigürasyonların sınırları ile örtüşmez. Hatta kentsel hareketlilik, teknolojik unsurların devreye girmesi, insan-nesne etkileşimi, sınırların ötesinde bu etkileşimlerin süresiz bir şekilde genişletilmesi ile farklı düzlemlerde ilişki şebekeleri ve katmanları oluşturmaktadır.

2. Metodolojik Şehircilik Yerine Olasılıklar ve Rastlantısallıklar: Milieu'ler toprak ve mekânla ilintilenmez ve herhangi bir mekân içerisindeki unsurların örtüşen ve kesişen yönleri, hareketleri, bileşenler, halleri ile alg1 ve eylemlerinin boyutsal bir soyut düzlemden bahsedilir. Bu düzlemde yazılı olmayan bir hukuk olduğunu ve bunun mekânın dağıtımı ve mekân içindeki dağıtımdan ayrı düşülemez (Deleuze ve Guattari, 1987, s. 312). Böylelikle, KPE'nin metodolojik şehircilik tartışmasındaki birim analiz olarak süreç 
(kentleşme) ya da nesnelerin (kent) yerini milieu'ler alır. Böylelikle olasılıklar ve rastlantısallıklar ile birlikte bunları yarattığı siyaset ve güç ilişkileri açığa çıkar. Philo (2012), kentin çeperlerini, çevresini ve kırsal alanlarını da içerisinde barındırdığını ve hatta bunlara bağımlı olduğunu söyler. Milieu'yü, ekolojik birbirine bağımlılıkların birbirini nasıl etkilediği ve olasılık dengelerini hesaplamak için araştırılması gereken bir ortam olarak tanımlar (s.508).

Bileşenin periyodik tekrarı ile oluşan "bir zaman-mekân bloğu" (Deleuze ve Guattari, 1987, s.313) olarak tanımlanan milieu'nün dört biçimi tanımlanır: (1) Materyallerden oluşan diş milieu; (2) Element ve maddelerin oluşturduğu iç milieu; (3) Çeperlerin oluşturduğu aracı milieu; enerji kaynakları; (4) Eylem algılarının oluşturduğu ilişik milieu. Böylelikle, zaman ve mekândan bağımsız milieu, sosyo-bilişsel alan olarak ele alınabilir (Longhurst, 2015).

Bu açıdan da kentsel sınırların ortadan kalktığı bir analiz alanı imkânı ortaya çıktığı söylenebilir. Örneğin, kent suçu kapsamına giren "toprak üzerinde yapılan her türlü insan yapımı faaliyetin, canlı yaşamı, ekolojik döngüler, kentsel yaşanabilirlik ve sağlıklı bir çevre üzerinde yarattığı ve yaratacağı tahribat ve bozulmanın ortaya çıkmasına neden ol[ma]" (Kent Suçları, 2019) faaliyetleri bir tür sosyo-bilişsel alanın bir iktidar alanı haline gelmesi neticesindedir. Fiziksel mekân ötesindeki yatırımlar (dış milieu), dağıtım ilişkileri (iç milieu), bunlar arasındaki ilişkiler (aracı milieu) ile aktör ve aktanlar arasındaki çekişmeler, retorikler ve söylemler (ilişik milieu) üzerinden bir analiz metodolojik şehircilik eleştirisine yant olabilir.

\section{Sonuç Yerine}

Her ne kadar KPE kentleşmenin olgusunun ve sürecinin kavramsallaştırılmasında eksiklikleri ortaya çıkarmak ve yeni analiz alanları açmak için ortaya atılmış olsa da mevcut kavramları hala yetersiz kalmaktadır. Benzer bir sorunu, Ekim 2019 tarihinde Ankara'da düzenlenen 4. Uluslararası Kent Araştırmaları Kongresinde İlhan Tekeli de ifade etmiştir. Değişim ve dönüşümleri anlamda mevcut kavramların yeterli olmaması ve yeni kavramlara ihtiyaç duyulmaması dile getirilmiştir. Bu makale, bu tartışmalara katkı niteliğinde milieu kavramını harekete geçirilmesini önerir.

Makale, milieu kavramı üzerinden bir analiz ile, KPE literatüründeki tartısmaları irdeler. Bunlar özetle şu şekildedir: kentin ne olduğu ve kent-doğa ayrımına ilişkin tartısmalar; inter-disipliner, disiplinler-ötesi, politika, ekoloji ve siyasetin kent-doğa ayrımının ötesindeki araştırma alanlarında incelenebilmesi; kentleşme/kent tartı̧ması; metodoloji tartışması; konumlandırılmış KPE ve 
post-kolonyal yaklaşımlar ile antroposen bakış açısının eleştirilmesi; analiz biriminin sınırlarının çizilememesi; metodolojik determinizm sorunu; akış ve değişimleri takip etmekteki zorluklar; ikilemler (doğa-insan-nesne) içerisinde kalmak. Milieu kavramsallaştırması bu tartısmaların geride kalmasına ve daha eleştirel araştırma ve incelemelerin üretilmesine de firsat verir.

Milieu kavramı bir süreç analizi olarak bahsi geçen sorun alanlarına çözüm olabilir. Foucault'nun dolaşım ve nedensellik ilişkisi içinde tartıştığ 1 milieu kavramı kent-kentleşme ile neden-süreç analizleri de bir bütünlük ve derinlik kazanmış olur. Bedenler, nesneler, teknikler ve söylemlerin milieu kavramı içerisindeki analizi ampirik incelemeler ile KPE araştırma programı arasındaki bağlantıyı daha da kuvvetlendirebilir. Ayrıca, kent-kır, merkez-çeper, iç-dış ayrımları da ortadan kalkar ve milieu'yü oluşturan unsurlar arasındaki etkileşimler silsilesi ve ilişkiler sistemi olarak incelenebilir. KPE içerisinde kent-doğa ve Batı ve Batı-dışı ayrımlarını yıkma çabası milieu kavramı üzerinden daha etkin bir hale dönebilir ve salt ampirik veriler üzerinden vaka analizleri ile zengin KPE literatürünü kavramsal bir tutarlılığa da ulaştırabilir. Böylesine bir kavramsallaştırma metodolojik determinizmin eleştirisine de yanit olur zira salt kentler, kentleşme ya da salt fail, nesne ve doğa değil bu aktan, aktör ve süreçlerin etkileşime girdiği fiziksel ve kavramsal alan incelemesi de yaratıı bir politika analizine evrilebilir.

Yine,insanın doğaya hükmettiği, doğanın ve çevrenin edilgen kılındığ ve teknoloji-insan-doğa çekişmesinin ötesine geçmeyen tartı̧̧malar daha demokratik bir zeminde Foucault(2009) ve Latour'un(2009) nesne ve insanların eşit ele alındığı bir analizde ve milieu kavramının harekete geçirilmesi ile daha da anlam kazanabilir. KPE literatüründeki tartışmaların milieu kavramını anımsatan kavramsal tartısmaları mevcuttur. Fiziksel mekânın ötesindeki sosyo-ekolojik süreçlerin incelenmesi çabası bunu göstermektedir. Fakat fiziksel mekânın ötesine geçme noktasında çekingen davranan bu literatür metabolizma ve dolaşım süreçlerini salt fiziksel dolaşım olarak ele almaktadır. Bunlara etkileşimlerin siyaseti ile söylem ve retoriklerin girmesi ile daha geniş bir kavramsal alanda tartısılması gerekmektedir. Bu alan milieu olarak kavramsallaştırılabilir.

Henri Lefebvre milieu kavramını kültürel ve davranışsal boyutuyla ele almış olsa da, Lefebvre'nin kent teorisini açmayı ve harekete geçirmeyi ön gören KPE'nin, bu amacına ulaşmada bu milieu kavramı özelinde de bir ilerleme sağlamadığı söylenebilir. Lefebvre'nin (1991) "moda tabir" (s. 196) olarak ifade ettiği milieu ifadesinin KPE tartışmalarında göz ardı edilmiştir. Lefebvre'nin de belirttiği, tekrarlar ve ilişkiler, mekânın da ikili belirleyicilerini 
ortaya çıkarır. Burada, milieu doğrudan ya da aracılı bir geçiş ve bağlantı alanıdır (s.187). Oysa böylesine bir kavramsallaştırmanın zenginleştirilmesi KPE içerisindeki çelişkileri ve tutarsızlıkları da hafifletebilir. Böylelikle, KPE araştırmacıları yöntem ve ikilemler arasında kalmak yerine ilişkisel dinamikleri ve bağlantı sistemlerini irdeleyip daha eleştirel bir araştırma için daha üretken olabilirler. Lefebvre'nin (1991) milieu kavramına bakışı, yaşayan varlığın çevresinde ve onun eylemleri ile üretilen davranışsal alan olarak bir ilişkiler ağını resmeder ve bu mekansal milieu'de bu ağ bağlantılı olarak onunla birlikte hareket eden ve yine canlı tarafından belirlenen ve aynı anda gerçekleşen bir ağdır(s.175). Bu makale ise, davranışsal boyutun ötesinde bir milieu tanımı benimser. Buna göre, milieu, insan ve insan-olmayan unsurların oluşturduğu rastlantısallığın siyasetidir.

\section{Araştırmanın Kısıtları ve Yeni Araştırma Önerileri}

Makale doğrudan kentsel politik ekoloji literatürü ve onun yarattığ tartışmalara odaklandığı için politik ekoloji literatürüne değinmemiştir. Bir sonraki araştırma politik ekolojiden KPE'ye geçişin sebeplerini irdeleyebilir. Bu makale, KPE adı altında önerilen araştırma programının kısıtları dahilinde bir kuramsal bir tartışmayı açığa çıkarmaya çalışır. Bu tartışmanın ampirik düzlemde örneklerle zenginleştirilmesi anlamlı olabilir. Bu anlamda milieu üzerine yeni kuramsal açılımlar sağlayan farklı kaynaklara da danışılabilir (örneğin, Tekin Bilbil, 2019). Bir sonraki çalışmalar milieu kavramı tartışmalarında soru işareti yaratan "belirli bir mesafede" ifadesinin deşilmesi gereğidir. Foucault bunu, "within a given space" (bilinen/belirli bir alan/mekânda) ve "action at a distance of one body on another" (bir vücudun diğerine bir belirli/uzak bir mesafedeki hareketi) ifadelerinde mesafe kavramının nasıl farklı çağrısımlar ve analiz alanları yarattı̆ı incelenebilir. Bilginin siyaseti sorgulamasında, bu mesafe neye göre belirlenir, kim belirler ve burada herhangi bir sınır ön görülebilir mi? 


\title{
Extended Abstract
}

\section{Discussions within the Urban Political Ecology Literature: Does the Concept of Milieu Offer a Solution}

\author{
* \\ Ebru Tekin Bilbil \\ Özyeğin University \\ ORCID: 0000-0001-9916-1047
}

This article analyzes the Urban Political Ecology (UPE) literature as an interdisciplinary field of research by examining its emerging ideas and concepts. This literature urges new discussions regarding the concept of the city, the urban-rural distinction, the methodology problem with comprehensive empirical analyses. Despite this, there are still gaps in understanding social transformations and changes with the concepts of cyborg, planetary urbanization, metobolism, hybrid and so on. This article addresses these constraints by means of the concepts and discussions revealed within the literature of UPE. Therefore, by mobilizing the term of milieu, which is largely ignored in theoretical discussions within UPE, this article aims to contribute to the conceptual and empirical problems of the UPE literature. First, this paper analyzes the urban political ecology research program with different theoretical frameworks, different problem areas and different forms of conceptualization. Second, it examines the theoretical debates in the last 15 years. Third, the concept of milieu is addressed in order to contribute to these discussions. The study follows a research methodology based on secondary sources, since it includes a theoretical discussion. The origins and starting point of the UPE literature is grounded on different problems in understanding the process of urbanism and urbanization. These include methodological contradictions; the problem of urban-nature distinction; uneven development and thus increased globalization and capitalism; the conceptualization of power and force; agency; dynamics of change and transformation; and sustainability. Although each problem area has deep literature and conceptual links within itself, the urban-nature distinction is the constitutive problematic of the UPE literature. 
Deleuze and Guattari (1937) say that milieu and rhythms are born out of chaos. They argue that rhythms occur among many milieus that constantly transform and change each other while rhythms are related to land and region (p. 313). Milieus are coded by periodic repetition but these repetitions are not as precise and static as the metric. As milieus change, unite and articulate, these repetitions constantly transform, differentiate and change. In this sense, milieu emerges as an area of analysis that will reveal relational dynamics, probabilities and conditionality beyond a physical space. For Foucault, milieu's relations between circulation and causality as a field of intervention and control of relations are discussed within the security regime (Foucault, 2009 , p. 21). Beyond the passive conceptualization on the milieu, the performative and enabling role of it can be highlighted and thus its relational, instrumental and enabling factors can be discussed and revealed further micro power relations and hidden aspects of social problems. The constitutive elements of this milieu need to be revealed with a series and spatial-temporal uncertainty. This is regulated by bio-power within a transformable field (Johnson, 2008; Rose-Redwood, 2012), which is open to infinite intervention. For instance, milieu is a kind of platform in which the market is enabled as well as this platform is marketized and managed as a field of operation, reproduction and diffusion practices within a kind of "enterprise society" (Venn, 2009, p. 211). Moreover, with the opening of public spaces for market use, such a milieu might be analyzed in relation to the space emerged as a market instrument, uncertainties produced by means of power relations, as well as the governing of all these dynamics. For example, whilst urban projects create different milieus; the changing regulations and administration, infrastructure problems, lack of communication between institutions and interest relations interact within this milieu and produce conditionality.

The taken-for-granted concept of milieu by the UPE needs to be uncovered for an in-depth empirical and theoretical analysis. The milieu analysis can open up more space in order to address and ease the problem areas discussed within the UPE. As such, this paper mobilizes the concept of milieu due to the following contributions of the concept: (1) The milieu analysis reveals the system of relations rather than sole physical boundaries; (2) This milieu analysis focuses more on contingencies rather than limiting the social problems into methodological urbanism. 


\section{Kaynakça/References}

Adanalı, Y. A. (2011). De-spatialized space as neoliberal utopia: Gentrified Istiklal street and commercialized urban spaces. Red Thread, 3(2011), 1-13.

Adey, P. (2013). Air/atmospheres of the megacity. Theory, Culture E Society, 30(7-8), 291-308.

Akbulut, B., ve Candan, A. B. (2014). Bir-iki ağacın ötesinde: İstanbul'a politik ekoloji çerçevesinden bakmak. Yeni İstanbul Çalışmaları içinde, 288-299.

Aksümer, G., ve Yücel, H. (2018). Immaterial dimensions of the right to the city: The case of Istanbul's Derbent neighborhood in the urban transformation process. Planning, 28(1), 76-89.

Altınok, E., ve Enlil, Z. (2012). Mekânin yeniden organizasyonunun ekonomi politiği. Sigma, 4, 37-44.

Amin, A. ve Thrift, N. (2002). Cities: reimagining the urban. Polity.

Angelo, H., ve Wachsmuth, D. (2015). Urbanizing urban political ecology: A critique of methodological cityism. International Journal of Urban and Regional Research, 39(1), 16-27.

Arboleda, M. (2016). In the nature of the non-city: Expanded infrastructural networks and the political ecology of planetary urbanisation. Antipode, 48(2), 233-251.

Aydalot, P. (Ed.) (1986). Milieux innovateurs en Europe. Paris: GREM

Beyond Istanbul. (2019). İstanbul yollarmda kentsel politik ekoloji. Beyond Istanbul. MAP Akademi.

Camagni, R. (2005). Uncertainty social capital and community governance: The city as a Milieu. In Urban dynamics and growth: advances in urban economics (p. 121-150). Emerald Group Publishing Limited.

Candan, A. B., ve Kolluoğlu, B. (2008). Emerging spaces of neoliberalism: A gated town and a public housing project in Istanbul. New perspectives on Turkey, 39, 5-46.

Canguilhem, G. (2001). The living and its milieu. Grey Room, 7-31.

Coates, R. (2019). Citizenship-in-nature? Exploring hazardous urbanization in Nova Friburgo, Brazil. Geoforum, 99, 63-73.

Cornea, N. L., Véron, R., ve Zimmer, A. (2017). Everyday governance and urban environments: Towards a more interdisciplinary urban political ecology. Geography Compass, 11(4), e12310.

Crevoisier, O. (2004). The innovative milieus approach: Toward a territorialized understanding of the economy?. Economic Geography, 80(4), 367-379.

Deleuze, G., ve Guattari, F. (1987). A thousand plateaus. Vol. 2 of Capitalism and schizophrenia. Trans. Brian Massumi. Minneapolis: University of Minnesota Press.

Demaria, F., ve Schindler, S. (2016). Contesting urban metabolism: Struggles over waste-to-energy in Delhi, India. Antipode, 48(2), 293-313.

Depietri, Y., Kallis, G., Baró, F., ve Cattaneo, C. (2016). The urban political ecology of ecosystem services: The case of Barcelona. Ecological Economics, 125, 83-100. 
Doshi, S. (2017). Embodied urban political ecology: five propositions. Area, 49(1), 125128.

Eckers, M. ve Loftus, A. (2008). The power of water: developing dialogues between Foucault and Gramsci. Environment and Planning D: Society and Space 26 (4), 698718.

Erensu, S. (2015). Abundance and scarcity amidst the crisis of 'modern water': The changing water-energy nexus in Turkey. In Contemporary Water Governance in the Global South (p. 61-78). Routledge.

Ernstson, H., ve Silver, J. (2014). Provincializing urban political ecology: Towards a situated UPE through African urbanism. Antipode, 46(2), 497-516.

Foucault, M. (2009). (1977-78). Security, territory, population. lectures at the Collège de France, 1977-78, (Der. M. Senellart). (Ed. F. Ewald and A. Fontana). Palgrave.

Gabriel, N. (2014). Urban political ecology: Environmental imaginary, governance, and the non-human. Geography Compass, 8(1), 38-48.

Gustafson, S. (2015). Maps and contradictions: Urban political ecology and cartographic expertise in southern Appalachia. Geoforum, 60, 143-152.

Haraway, D. (2013). Simians, cyborgs, and women: The reinvention of nature. Routledge.

Harvey, D. (1973). Social Justice and the City. University of Georgia Press. Retrieved from www.jstor.org/stable/j.ctt46nm9v.

Harvey, D. (2009). Social justice and the city (revised edition). https://ebookcentral.proquest.com adresinden erişilmiştir.

Harvey, D. (1996). Justice, Nature and the Geography of Difference. Oxford: Blackwell Publishers.

Heynen, N. (2006). Green urban political ecologies: toward a better understanding of inner-city environmental change. Environment and Planning A, 38(3), 499-516.

Heynen, N. (2014). Urban political ecology I: The urban century. Progress in Human Geography, 38(4), 598-604.

Heynen, N. (2016). Urban political ecology II: The abolitionist century. Progress in Human Geography, 40(6), 839-845.

Heynen, N. (2018). Urban political ecology III: The feminist and queer century. Progress in Human Geography, 42(3), 446-452.

Heynen, N., Kaika, M., ve Swyngedouw, E. (Eds.). (2006). “Urban political ecology: politicizing the production of urban natures". (Heynen, N., Kaika, M., ve Swyngedouw, E. Eds.). The nature of cities: urban political ecology and the politics of urban metabolism içinde. Routledge.

Johnson, P. (2008). The modern cemetery: a design for life. Social \& Cultural Geography, 9(7), 777-790.

Kaika, M., ve Swyngedouw, E. (2011). The urbanization of nature: Great promises, impasse, and new beginnings. The new Blackwell companion to the city, 96-107.

Karaman, O. (2012). An immanentist approach to the urban. Antipode, 44(4), 12871306. 
Karpouzoglou, T., Marshall, F., ve Mehta, L. (2018). Towards a peri-urban political ecology of water quality decline. Land Use Policy, 70, 485-493.

Keil, R. (2005). Progress report-urban political ecology. Urban Geography, 26(7), 640651.

Keil, R. (2011). Transnational urban political ecology: Health and infrastructure in the unbounded city. The new Blackwell companion to the city, 713-725.

Keil, R. (2003), Progress report: Urban political ecology. Urban Geography, 24, 723738.

Kent Suçları. (2019). Kent suçları haritası. http://kentsuclari.org/ adresinden erişilmiştir.

Latour, B. (2004). Politics of nature. Harvard University Press.

Latour, B. (2009). A collective of humans and nonhumans: Following Daedalus's labyrinth. Readings in the Philosophy of Technology, 11.

Lawhon, M., Ernstson, H., ve Silver, J. (2014). Provincializing urban political ecology: Towards a situated UPE through African urbanism. Antipode, 46(2), 497-516.

Lefebvre, H. (1976). The survival of capitalism: reproduction of the relations of production. St. Martin's Press.

Lefebvre, H. (1991). The production of space. Oxford. (original. edition 1974.)

Legg, S. (2011). Assemblage/apparatus: using Deleuze and Foucault. Area, 43(2), 128133.

Lewis, R. (2017). Comments on urban agency: relational space and intentionality. Urban history, 44(1), 137-144.

Liu, S., Costanza, R., Troy, A., D’Aagostino, J., ve Mates, W. (2010). Valuing New Jersey's ecosystem services and natural capital: a spatially explicit benefit transfer approach. Environmental management, 45(6), 1271-1285.

Longhurst, N. (2015). Towards an 'alternative'geography of innovation: Alternative milieu, socio-cognitive protection and sustainability experimentation. Environmental Innovation and Societal Transitions, 17, 183-198.

López-Durán, F., ve Moore, N. (2018). Meat-milieu: medicalization, aestheticization and productivity in Buenos Aires and its Pampas, 1868-1950. Urban History, 45(2), 253-274.

Malmberg, A. (1996). Industrial geography: agglomeration and local milieu. Progress in Human Geography, 20(3), 392-403.

McCann, E., Roy, A., ve Ward, K. (2013). Assembling/worlding cities. Urban Geography, 34(5), 581-589.

McKinnon, I., Hurley, P. T., Myles, C. C., Maccaroni, M., ve Filan, T. (2017). Uneven urban metabolisms: Toward an integrative (ex) urban political ecology of sustainability in and around the city. Urban Geography, 1-26.

Monstadt, J. (2009). Conceptualizing the political ecology of urban infrastructures: insights from technology and urban studies. Environment and planning A, 41(8), 19241942. 
Ovacık Çoruh, D. (2018). Kentsel ortam [Milieu]: Özneleş[tir]meye yönelik manipülasyon ve "karşı-özneleşme" pratiği için motivasyon alanı. Tez. İstanbul Teknik Üniversitesi, Fen Bilimleri Enstitüsü, İstanbul.

Ovacık Çoruh, D. ve Uluoğlu, B. (2018). Bir karşı-özneleşme [yeniden-özneleşme] pratiği olarak tasarım. Erciyes Üniversitesi Sosyal Bilimler Enstitüsü Dergisi, 32(44), 163193.

Özberk, N. (2017). 'Kentsel yıkımın' politik ekolojisi: Nevşehir Kalesi ve çevresi kentsel dönüşüm projesi örneği. İdealkent, 8(21), 200-228.

Öztürk, M., Hilton, A., ve Jongerden, J. (2014). Migration as movement and multiplace life: some recent developments in rural living structures in Turkey. Population, Space and Place, 20(4), 370-388.

Peet, R. ve M. Watts (2000). Liberation ecologies: environment, development, social movements. Routledge, New York, NY and London.

Philo, C. (2012). A 'new Foucault'with lively implications-or 'the crawfish advances sideways'. Transactions of the Institute of British Geographers, 37(4), 496-514.

Ribeiro, L. C. D. Q., ve Santos Junior, O. A. D. (2017). Neoliberalization and megaevents: The transition of Rio de Janeiro's hybrid urban order. Journal of Urban Affairs, 39(7), 909-923.

Rice, S., ve Tyner, J. (2017). The rice cities of the Khmer Rouge: an urban political ecology of rural mass violence. Transactions of the Institute of British Geographers, 42(4), 559-571.

Rose-Redwood, R. (2012). With numbers in place: Security, territory, and the production of calculable space. Annals of the Association of American Geographers, 102(2), 295-319.

Roy, A. (2016). What is urban about critical urban theory?. Urban Geography, 37(6), 810823.

Samec, T., ve Gibas, P. (2018). Urban political ecology of worth and value: Enacting allotments in media discourse. Space and Culture, 1206331218806169.

Soens, T. (2019). Introduction. İçinde (Soens, T., Schott, D., Toyka-Seid, M., ve De Munck, B. Eds.). (2019). Urbanizing Nature: Actors and Agency (Dis) Connecting Cities and Nature Since 1500. Routledge.

Soens, T., Schott, D., Toyka-Seid, M., ve De Munck, B. (Eds.). (2019). Urbanizing Nature: Actors and Agency (Dis) Connecting Cities and Nature Since 1500. Routledge.

Söderström, O., Empson, L. A., Codeluppi, Z., Söderström, D., Baumann, P. S., ve Conus, P. (2016). Unpacking 'the City': an experience-based approach to the role of urban living in psychosis. Health $\mathcal{E}$ place, 42, 104-110.

Swyngedouw, E. (1996) The city as a hybrid -- On Nature, society and cyborg urbanisation. Capitalism, Nature, Socialism, 7(25), 65-80

Swyngedouw, E. (1997). Power, nature, and the city. The conquest of water and the political ecology of urbanization in Guayaquil, Ecuador: 1880-1990. Environment and planning $A, 29(2), 311-332$. 
Swyngedouw, E. (2006). 2 metabolic urbanization. The Nature of Cities: Urban Political Ecology and the Politics of Urban Metabolism, 21.

Swyngedouw, E., ve Heynen, N. C. (2003). Urban political ecology, justice and the politics of scale. Antipode, 35(5), 898-918.

Swyngedouw, E., Kaika, M., ve Heynen, N. (2006). Urban political ecology: politicizing the production of urban natures. İçinde In the Nature of Cities (s.16-35). Routledge.

Tekin Bilbil, E. (2019). Yönetişim ve yönetimsellik: Kentsel mekan ve ortam. Siyasal Kitabevi: Ankara.

Terranova, T. (2004). Communication beyond meaning: On the cultural politics of information. Social Text, 22(3), 51-73.

Terranova, T. (2009). Another life: The nature of political economy in Foucault's genealogy of biopolitics. Theory, Culture \& Society, 26(6), 234-262.

Truelove, Y. (2011). (Re-) Conceptualizing water inequality in Delhi, India through a feminist political ecology framework. Geoforum, 42(2), 143-152.

Tuçaltan, G. (2017). Metabolic Urbanization of waste in Ankara: A governance perspective. Utrecht University.

Usher, M. (2014). Veins of concrete, cities of flow: Reasserting the centrality of circulation in Foucault's analytics of government. Mobilities, 9(4), 550-569.

Venn, C. (2009). Neoliberal political economy, biopolitics and colonialism: A transcolonial genealogy of inequality. Theory, Culture \& Society, 26(6), 206-233.

Venn, C., ve Terranova, T. (2009). Introduction: Thinking after Michel Foucault. Theory, Culture \& Society, 26(6), 1-11.

Whitehead, M., (2005). Between the marvelous and the mundane: Everyday life in the socialist city and the politics of the environment. Environment and Planning D: Society and Space, 23, 273-294.

Zeybek, S. O. (2011) Small towns in Turkey: Footnotes in somebody else's history. Journal of Historical Sociology, 24(1), 100-115.

Zeybek, S. O. (2016). Ekolojinin politikası: Yeni sınırlar, yeni aktörler. Toplum ve Bilim, 138(139), 7-25.

Zimmer, A. (2010). Urban political ecology: Theoretical concepts, challenges, and suggested future directions. Erdkunde, 343-354.

Zizek, S. (2012). Antroposen'e hoşgeldiniz. Encore Publications: İstanbul. 


\section{Ekler}

\section{Kentsel Politik Ekoloji Okuması Üzerinden Foto-Metin}

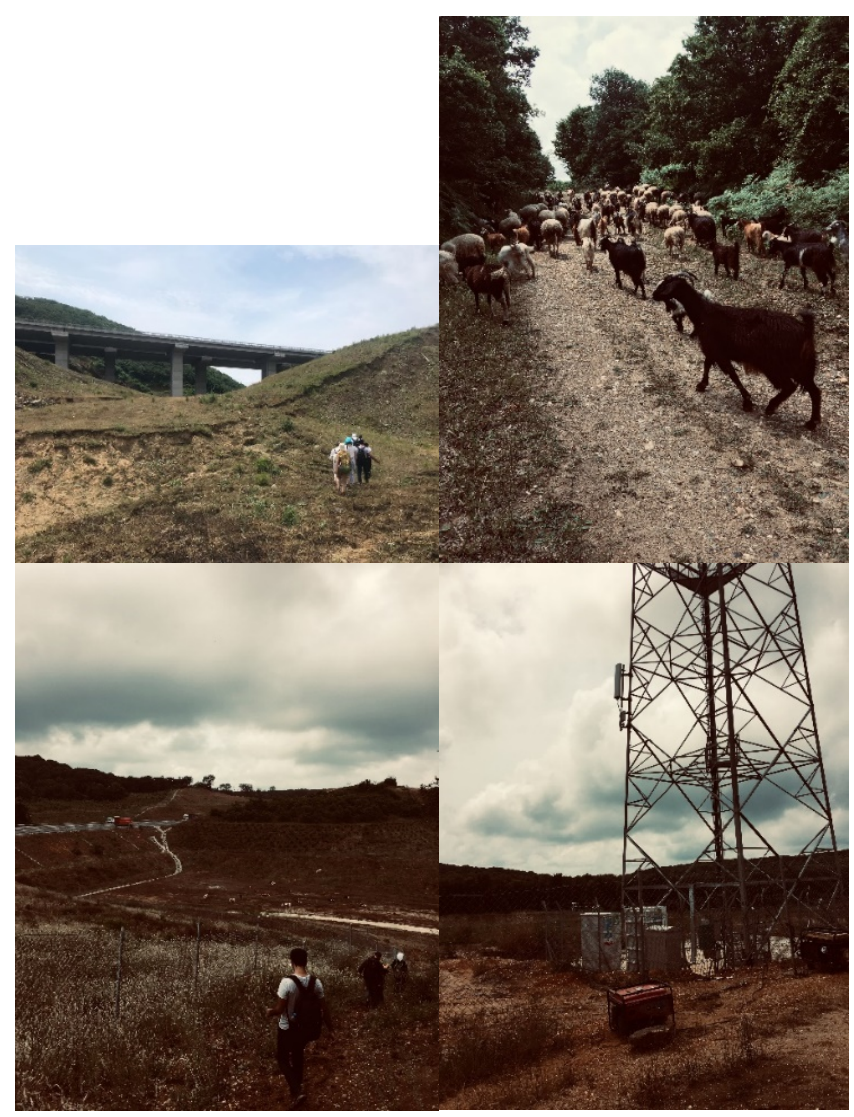

Kısırkaya Köyü ve Kuzey Marmara Otoyolu - 3. Havalimanı Yönü

$\mathrm{Bu}$ fotoğrafta ufukta bir küresel taşımacılığın ve dolaşımın simgesi bir tır ormanı delen devasa bir otobanda hizla ilerlerken otoban kenarında doğaotoban-doğa içerisinde kalan bir grup insanı resmediyor. $\mathrm{Bu}$ insanlar orada ne yapıyor sorusundan ziyade o insanlar otoban kenarında nasıl ve neden ilerleyemiyor? Doğadan otobana doğru giderken sesler o insanlar için ne ifade ediyor? $\mathrm{Bu}$ otoban olmadan kent beslenemez mi? O tırın buradan geçmesinin zorunlu olması kentin diğer huzursuz unsurları ile nasil bir sebep-sonuç etkileşimi içerisinde olabilir? Kenti besleyen kaynaklar ve kanallar neler, nereden nasıl bir dönüşümle geliyorlar? Kent, insanlar ve bunlara eklemlenen aktanlar ve diğer canlılar kentin kuzey çeperlerinde bu fotoğrafta bir araya geliyor Foto: Yazar, Mekanda Adalet Derneği KPE Yaz Okulu, İstanbul, 2019. 